\title{
The Value of Education in a Marriage
}

\author{
Azmil Mukarrom \\ Universitas Sunan Giri Surabaya \\ azmilmukarrom@gmail.com
}

\begin{abstract}
Background of the Problem Islam is a religion that is Shamil or covers all aspects of human life from the fundamentals of one's life even to the very small and trivial things in life itself. Among the things that are very urgent that every human will experience is the process of marriage. What is certain is that Islam does not escape giving signs and teachings that must be known by every human. With the hope that everything he does is in accordance with the guidance of Islamic shari'ah itself. Marriage in Islam is peace of mind, peace of mind, and determination. Truly marriage is a relationship of two hearts that is very powerful. Allah binds both of them to provide peace and inner peace in a household full of love and warmth. The Qur'an describes the eternal bond between men and women with a very beautiful picture. It can provide security and calm. In it there is a very noble educational process. Alloh $\mathrm{l}$ explained through His Messenger $\mathrm{n}$ will be a very valuable education in the bond of marriage.
\end{abstract}

Keyword : Value, Education, Marriage

\section{DISCUSSION}

Marriage Marriage in Islam is peace of mind, peace of mind, and resolve (Hasyimi, 2012). Truly marriage is a relationship of two hearts that is very powerful. God binds both of them to provide inner peace and tranquility in a loving and warm home. Based on Islam's glorious view of marriage, a true Muslim will not be tempted by the beauty of women today. From this a Muslim not only looks at beauty and beauty, but besides that all are also required to have a righteous religion, a strong mind, and a good life journey. It is based on the instructions of the Prophet:

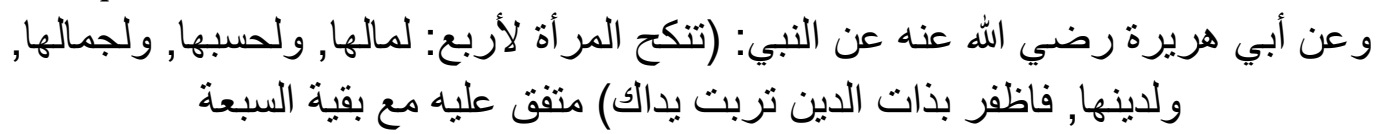

From Abu Hurairah Radliyallaahu 'anhu that the Prophet sallallaahu' alaihi wa Sallam said: "The woman was married because of four things, namely: wealth, descent, beauty, and religion. Get a religious woman, you will be happy. "HR.Bukhori (Zabidy, 2009). 


\section{Shari'ah Hadith}

This hadith explains that things that make men interested in marrying women are because of the four qualities that are owned by the woman, and the most recent characteristic is because of her religion. Then, the Prophet SAW ordered the youth if he wanted to get married, then he found a woman who was religious, so let him not turn away from him, because there was a prohibition on marrying a woman who was not because of his religion (Ismail, 2011). In the hadith that is explained by an-Nasa'i and Abu Hurairoh explained the good qualities for women, that the Messenger of Allah was asked, "O Messenger of Allah, what are the criteria for the best woman? The Prophet replied, 'A woman who can make you happy when you look, a woman who obeys you when you command, and a woman who is faithful and can look after her property' (Ismail, 2011). (this hadith saheeh) Saheeh aljami '.

And the word "الحسب" is also interpreted with good behavior for her husband and parents, and also interpreted as devotion. This hadith shows that making friends with religious people is more important, because it can take advantage of the good character that it has. Especially for a wife to be a religious person, because she is the life companion of a husband, mother to children, guardian of the trust in property, home and himself at his own time. Just as Islam has inherited women and their high position, Islam also commands a woman to know her role in life, so that she is in her treatise and able to play her perfect role. Together with her husband in fostering generations, refreshing life with pleasure, happiness and beauty (Hasyimi, 2012).

\section{Correlation of Marriage in the World of Education}

Character of educators As we know that the purpose of Islamic education is the creation of human beings(Ramayulis, 2012) which is a real manifestation of obedience and submission as a form of devotion to Allah. To actualize these goals in Islamic education, an educator has the responsibility of leading students towards these goals [8]. An educator has a very crucial role, an educator is not only transforming (transfer of knowledge) knowledge but is also required to internalize the values in students.

So an educator must have positive personality traits (Ramayulis, 2012). In this hadith an educator / teacher must be professional in educating his students, do not be underestimated, to students who we think are lacking in everything, ranging from wealth, descent, beauty / good looks of students. But what we must pay attention to is his religion, or whether he really needs knowledge from us. We must educate him well and convey knowledge to him even though one verse. Especially we must educate a student must look at his religion, so that what we will convey is not contrary to the teachings of his religion, especially in religious education subjects. 
As Allah explained in the Koran that the noble position of humans is not due to wealth or poverty, but devotion [10] which is the benchmark of human glory on his Rabb. Allah says in the Qur'an Surat al-Hujurat verse 13 Which is mean " $O$ people, Verily We created you from a man and a woman and made you nation people and tribes so that you know each other.There is the most noble person among you Allah is the most pious among you Truly, Allah is Knower, .

From here we can implement this verse in educators to always be fair to their students, Justice towards children is intended so that children have equal rights both in grants , living, education, etc., as well as receiving inheritance (Majid Khon, 2012)

Likewise, a teacher's justice for his students is always demanded as is the justice of his parents towards his children, this will create a conducive and lively atmosphere. will educate them.

Role of the Family In Islam the family is known as usrah, nasl, nasb. While in anthropological content is a smallest component that is owned by humans as social beings who have a residence that has a place to live (Abdul Mujib, 2010). In an educational process there are institutions that play a role in it. Among these institutions is the family which is the first and foremost education.

As first and foremost education, family education can print children to have personalities which can then be developed in subsequent institutions, so that the authority of these institutions is not allowed to change what they already have, but rather to combine between education obtained from family with other educational institutions. Educators in the family environment are parents. This is due to the natural behavior of children in the early days of their lives in the midst of their parents. From them the children begin to recognize their education. The basic outlook on life, life attitudes, and life skills are always embedded since the child lives in the middle of his parents. Thus parents are required to be educators who provide knowledge to their children, as well as provide positive attitudes and adequate skills both physically and spiritually.

So for the sake of the realization of success in family education it is very necessary the figure of parents who have the soul of educators for their children. Father. Which is a central figure in the family, a source of power that provides education for children about management and leadership, provides communication education to each other, provides a sense of security and protection, so that the figure of the father always provides an attitude of education that is always responsible and alert. Educators the basics of developing reason and intellectual power, so that gave birth to intellectual intelligence (Mujib, 2010).

Mother. Has a major role in the formation and education of their children in the family, because the nature and function is more directed to the task. A mother provides education for her children, friendliness, compassion and fostering. 
Caregivers and carers in the family who provide education in the form of loyalty to responsibilities. A place for giving heart education in the form of candor.

As educators in the emotional field of children who can educate their children in the form of sensitivity to perceive things, which gives birth to emotional intelligence. So for the achievement of the function of parents as educators in the family, the educational background and environment of the parents would certainly be a factor influencing this success. Thus the process of selecting a prospective husband and wife both in terms of religion, education and descent is highly recommended in marriage. This is suggested by the Shari'a as a manifestation of the theory of prenatal education (tarbiyah qabl alwiladah)(Ramayulis, 2012).

So that the educational process starts from the start of the family institution, both the mate selection phase, marriage, childbirth, until the internalization of the value phase itself, because this will provide a very significant influence on the growth of children both in terms of physical and psychological.

\section{CONCLUSION}

First, based on the implied will of the Messenger of Allah n, in the hadith about marriage, it can be concluded that Islam educates humans towards the plenary human level with the standard of devotion to Allah. So that the standard qualifications of virtue and success of students and educators is their religion, in this case Islam. Even so, Islamic education also carries a curriculum of justice that is used in the education process itself. Where the attitude of an educator must be fair in conveying lessons, without seeing students who are rich or poor, smart or less smart, handsome or not and other things that are tendential. All that goes back to the initial qualification standard, which is one's religion or devotion to his Rabb. Secondly, it can be concluded that there are so many principles that are closely related in the world of education from marriage. This is because marriage itself is part of the education system, which states that marriage is one of the processes in the prenatal education stage. This education begins when marriage preparation is good in the matter of choosing a mate, educating a small family, education during pregnancy, until the child - who is the object of students or students - accepts the transformation of knowledge and internalization of values and norms in the family.

\section{REFERENCES}

Al-Zabidy. Zainuddin Ahmad bin Abdullathif. 2009. Ringkasan shohihn Bukhari, Lahore: Dar Al-Kitab Wa Al-Sunnah.

Ash-Shan'ani. Muhammad bin Ismail al-Amir. 2011. Subulus salam, Jakarta: Darus Sunnah Press. 


\section{Edutec}

Journal of Education And Technology

Hasyimi. Muhammad 'Ali, Syakhshiyatul Muslim. Jakarta: Al-i'tishom, 2012. Khon. Abdul Majid. 2012. Ilmu Pendidikan Islam Hadis Tarbawi, Jakarta: Kencana Prenada Media Group.

Mujib. Abdul dan Jusuf Mudzakkir. 2010. Ilmu Pendidikan Islam, Jakarta: Kencana Prenada Media Group.

Ramayulis. 2012. Ilmu Pendidikan Islam,Jakarta: Kalam Mulia. 